\title{
JAPAN'S RESPONSES TO CHINA'S ECONOMIC INCENTIVES AND INITIATIVES TOWARDS ASEAN
}

\begin{abstract}
Mohd Ikbal Mohd Huda
Official socio-economic cooperation towards peace, stability, development and prosperity between ASEAN-Japan started with the Synthetic Rubber Forum in 1973. Facing various geopolitical challenges in 43 years, ASEAN-Japan cooperation has left a positive impact in the development of Southeast Asian economy and society. Stimulated by projected trade growth and strong economic ties, ASEAN and Japan continue to enjoy a close relationship built on the principle of 'heart to heart' through the Fukuda Doctrine of 1997. Although ASEAN and Japan remain key partners, the relationship has faced various challenges in the $21^{\text {st }}$ century. Among the major challenges that affect relations between Japan and ASEAN is the rise of China as a major power in the East Asian region. Economic cooperation being a major aspect in the interaction of China and ASEAN has created economic competition between China and Japan in Southeast Asia. This research examines Japan's response to China's economic incentives and initiatives towards ASEAN. Research shows that Japan's responses includes Free Trade Agreement (FTA), development of infrastructure connectivity, and strategic partnership.
\end{abstract}

Keywords: Japan, China, Economic, Incentives, Initiatives, ASEAN

\section{Introduction}

Economic cooperation between ASEAN and Japan in the last few decades has contributed to regional economic interdependence, advent of economic growth in ASEAN countries, and also regional stability. However, with significant changes in the present structural regional environment, this possesses new challenges for ASEAN - Japan relations. The obstacles faced by ASEAN - Japan cooperation is due to Japan's declining presence in ASEAN. By the end of the Cold War, Japan was expected to play a more comprehensive and responsible role as ASEAN's major economic partner. Unfortunately the collapse of Japan's bubble economy in the early 1990s led to a period of economic stagnation known as the Lost Decade. Still, Japan's role as ASEAN's economic partner is decreasing due to the fact that ASEAN's rapid economic growth has been tremendous. For example in 1995, Japan's GDP was seven to eight times larger than ASEAN. Now it is only two times larger. When we look at investments, trade and tourism, Japan's role in ASEAN is becoming relatively smaller because of other emerging economies.

Another hindrance in ASEAN Japan relations is due to the problem of trade constraints. Although fallen tariffs has alleviated trade between Japan and ASEAN, particularly with unilateral tariff reduction, which has been achieved through preferential trade agreements, however, long standing issues of access to the Japanese market for ASEAN goods still remains. For ASEAN, finding market access for exports is significant. Access to Japanese market is highest in the agricultural sector. Through the establishment of Free Trade Agreements (FTA) with ASEAN as a whole and seven ASEAN members bilaterally, has enable Japan to use its dominance in putting 
off negotiations over the elimination of agricultural tariffs by offering benefits in the form of economic cooperation. ${ }^{1}$

There are also new challenges to the ASEAN-Japan relation in the changing regional environment which has seen the increasingly central role played by ASEAN in the new emerging regional order in East Asia. Various ASEAN-led institutions such as ASEAN Regional Forum and ASEAN Plus Three have contributes to regional order. In order to maintain its centrality over the East Asia regional integration processes, ASEAN has cultivated closer relationships with major power while striving to maintain independence from competing major powers. In the process to enhancing cooperation, ASEAN has concluded FTAs with other partners such as China, South Korea, Australia and New Zealand, India. ${ }^{2}$ In other words ASEAN has diversified its relations to avoid depending too much on a single country.

More importantly, the challenge in ASEAN and Japan relations is being shaped by the rise of China. This has created growing competition between China and US in particularly the leadership arena in the regional integration process. While under President Obama, the US pushed pushed for the establishment of a region wide economic block under the Trans Pacific Partnership Agreement (TPPA), China has constantly favored the Regional Comprehensive Economic Partnership (RCEP) as the main regional economic architecture in East Asia. Furthermore, China's intention through the creation of the new institution Asian Infrastructure Investment Bank (AIIB) can be argued as an act of 'soft revisionism' where it is now eyeing regional leadership by not only seeking to play a larger role in the international scene but also want to changes 'how the game should is played'. This ever growing rivalry between China and the US could undermine the solidarity and centrality of ASEAN in the regional process, as ASEAN member states might find it difficult to achieve the right balance in relations between the US and China while keeping ASEAN as one solid entity. ${ }^{3}$ For example, with regards to the contents of the RCEP, Singapore and Malaysia have called for wide-ranging liberalization, that includes not only goods but also services and investment, whereas Indonesia which is on the receiving end of a flow of cheap Chinese goods and is concerned about a ballooning trade deficit with China, is opposed to FTAs with higher liberalization rates. Thus, ASEAN members are not even in agreement on the broad framework for the RCEP. However, with the failure of the TPPA under President Trump, the RCEP is now gaining more traction.

Failure to issue a joint communique in 2012 over the South China Sea is another example of the growing conflict of interests between ASEAN members in dealing with major powers which severely undermines ASEAN's centrality in regional process. Hence, in order to maintain its cohesion among its member countries, ASEAN has initiated its own goal for deeper integration. The ASEAN Secretariat has vowed to transform ASEAN into an ASEAN Economic Community by 2015 which features "a single market and production base, a highly competitive economic region, a region of equitable economic development, and a region fully integrated into the global economy". Japan, being the largest contributor towards the creation of AEC, has generously provided a huge amount of aid to narrow the gap among ASEAN members particularly Cambodia,

\footnotetext{
${ }^{1}$ Takashi Terada, "Japan-ASEAN Partnership in an Era of Multiple Regional Integration Frameworks" in Rizal Sukma \& Yoshihide Soeya (eds.), Navigating Change: ASEAN-Japan Strategic Partnership in East Asia and in Global Governance, JCIE: Tokyo, 2015.

${ }^{2}$ Mie, "Challenges to the New ASEAN-Japan Partnership in the Changing Regional Circumstances," Djapan Foreign Policy Forum, No. 20, 2014, available at http://www.japanpolicyforum.jp/pdf/2014/no20/DJweb_20_dip_02.pdf

${ }^{3}$ Takashi Terada, "Japan-ASEAN Partnership in an Era of Multiple Regional Integration Frameworks" in Rizal Sukma \& Yoshihide Soeya (eds.), Navigating Change: ASEAN-Japan Strategic Partnership in East Asia and in Global Governance, JCIE: Tokyo, 2015.
} 
Laos, Myanmar and Vietnam (CLMV). However, to date, the AEC has not been fully realized due to other challenges in functioning as an effective integrated economic body. Economic barriers that prevent economic flow have not been removed completely. This involves addressing tariffs and non-tariff barriers. Positive changes have been visible with tariffs having significantly fallen among the developed ASEAN 6 economies with more than 99 percent having being eliminated. Similarly the CLMV countries have eliminated about 90 percent of tariffs but progress in eliminating non-tariff barriers to trade, liberalizing services trade, Foreign Direct Investment (FDI), the flows of capital and the movement of skilled labour are very slower and have been a hindrance to intra-ASEAN trade. ${ }^{4}$ Furthermore, there is still a lack of a unified system for the regulation of trade and investment facilitation. An example is Indonesia that still institutes import quotas and requirements for domestic product sales, a problem that ASEAN has not overcome. ${ }^{5}$

Hence, while Japan has enjoyed influence and cordial relations with ASEAN countries, nevertheless the structural changes brought on by the rise of China and Beijing's rapid progress in relations with ASEAN as a collective group and bilateral interactions, have caused Japan to rethink its strategy of engagement towards ASEAN.

\section{Theoretical Framework}

Neorealism theory basically deals with how states interact regionally and internationally. As states are the main actors in the world, there is an absence of authority in regulating states behavior. In a competitive environment, such a vacuum allows the existence of anarchy. Therefore, the fundamental interest of states is to survive in relations to adequate measures for their own security. Which means, states formulate their policies based on security threat perceptions.

States are unable to perceive the true intention of other states and equally are ignorant about the capabilities of other states. Hence, states worry about their capabilities relative to the other states. Waltz argues this will lead to states that share similar interests to become allies achieve balance of power in order to survive to prevent hegemonic aspirations. ${ }^{6}$ In other word, states cooperate with each other in the international system to realize their own respective national interests. On the other hand, according to Mearsheimer, security dilemmas will increase as great powers possess capabilities which in turn decreases the security of other states. ${ }^{7}$ Hence, the best way for states to secure survival is by maximizing their own power and putting their own interests above the other states. Therefore, by shifting power in their favor, states achieve control. Through this, Neorealist have a wider definition of power pertaining to national interests that include economic interests and territorial integrity. In this essay, the following sections will examine Japan's relations with ASEAN through three types of variables (see Diagram 1).

\footnotetext{
${ }^{4}$ Masahiro Kawai, Moe Thuzar and Bill Hayton, “ASEAN's Regional Role and Relations with Japan: The Challenges of Deeper Integration," Paper presented at the Conference of Chatham House, February 22, 2016. https:/www.chathamhouse.org/sites/files/chatham\%20house/publications/research/2016-02-18-asean-regional-rolekawai-thuzar-hayton.pdf

${ }^{5}$ Takashi Terada, "Japan-ASEAN Partnership in an Era of Multiple Regional Integration Frameworks" in Rizal Sukma \& Yoshihide Soeya (eds.), Navigating Change: ASEAN-Japan Strategic Partnership in East Asia and in Global Governance, JCIE: Tokyo, 2015.

${ }^{6}$ Kenneth Neal Waltz, Theory of International Politics (Illnois: Waveland Press, Inc), 1979.

${ }^{7}$ John J. Mearsheimer, The Tragedy of Great Power Politics (New York: W.W.), 2001.
} 


\section{Diagram 1: Variables in Japan-ASEAN Relations}

\begin{tabular}{|c|c|c|c|c|}
\hline Independent Variable & & Intervening Variable & & Dependent Variable \\
\hline $\begin{array}{l}\text { Geo-economic and } \\
\text { political interest }\end{array}$ & $\rightarrow$ & $\begin{array}{l}\text { Domestic political } \\
\text { factors }\end{array}$ & $\rightarrow$ & $\begin{array}{c}\text { Japan strategic behavior } \\
\text { towards China economic } \\
\text { initiatives and incentives } \\
\text { in Southeast Asia }\end{array}$ \\
\hline
\end{tabular}

Source: Author's summary

\section{ASEAN and Japan in Regional Cooperation}

By the end of the Cold War not only was Japan able to build strong political cooperation with ASEAN, but more importantly, it influenced ASEAN tremendously. Perceived as sharing a common identity of being an Asian country in contrast with Western powers, as well as, it close economic cooperation with ASEAN, Japan was increasingly viewed as a potential regional leader by ASEAN countries in the context of Asian regionalism. Japan's role in regionalism began with the setting up Pacific Trade and Development Forum (PAFTAD) and the Pacific Basin Economic Council (PBEC) which included ASEAN members. Later Japan was instrumental in establishing the Asia Pacific Economic Cooperation (APEC) in 1989. However rather than being confined to East Asia alone, the membership of APEC with the urging of Japan included countries from the wider Pacific area. Asian growth brought about the seemingly decline in US relative power. Though APEC, Japan's objective was to tie the US to the region as an insurance for regional stability. Nevertheless, ASEAN countries perceived the APEC establishment suspiciously of possibility undermining ASEAN's position. APEC responded it will support ASEAN's role, by emphasizing on open trade, open markets and the General Agreement on Tariffs and Trade (GATT) / World Trade Organization (WTO). ${ }^{8}$

For Japan and ASEAN, maintaining policy of non-binding, voluntary and respect of sovereignty was crucially important. Hence, the US' aggressive trade policy in APEC was hard to accept. Efforts to turn the APEC into something more binding were at odds with Japan which advocated 'flexibility' in the application of APEC proposals. The proposal for the creation of the East Asian Economic Grouping (EAEG) by the Malaysian Prime Minister, Dr. Mahathir Mohamad in 1990 became the first attempt to establish a regional economic bloc exclusively just for East Asian countries that included ASEAN with Japan as the bloc leader. The proposal was primarily driven out of fear from the imminent formation of the European Committee (EC) and the North American Free Trade Agreement (NAFTA). For East Asian countries particularly ASEAN

\footnotetext{
${ }^{8}$ Michael Sutton, "Open regionalism and the Asia-Pacific: Implications for the rise of an East Asian economic community," Ritsumeikan Annual Review of International Studies, Vol. 5, pp 133-152, 2007, available at http://www.ritsumei.ac.jp/acd/re/k-rsc/ras/04_publications/ria_en/5-07.pdf
} 
members, the creation of NAFTA will not only threaten the access to US market but also the possibilities of facing direct competition from Mexico. ${ }^{9}$

The EAEG proposal eventually failed to materialize, due to lack of support from the US and Japan. US opposition to the suggestion came out of from fear of a 'closed regionalism' concept that would draw a boundary in the Pacific between East Asia and NAFTA while Japan was hesitant of the EAEG idea as it contradicted with what Japan belief of open regionalism rather than exclusive to East Asia. Japan also rejected the EAEG because the US was excluded from the grouping. ${ }^{10}$ Japan's lack of support of the EAEG also echoed its refusal over ASEAN's request to participate in the East Asia-Europe Meeting (ASEM) in 1995. Japan refused because the initiative rejected Singapore and the US. ${ }^{11}$ Hence, from the early post-Cold War era, Japan always maintained that East Asian regional affairs must be tied to maintaining US presence in the region.

Since the 1990s, Japan's slow economy resulted in the 'The Lost Decade'. Therefore, in order to escape from low growth and to recover, it was necessary to develop an economic environment in which labour and capital as factors of production could function efficiently. ${ }^{12}$ Japan's Free Trade Area's (FTA) participation will help in removing restrictions to the movement of labor and capital so that its economic growth can function perfectly. At the same time, the rapid growth in the proliferation of FTAs in the other places such as North American's NAFTA and EC in Europe has caused Japan to feel discriminated and it began to lose export potential from its traditional market area. Analysis found that Japanese businesses complained bitterly about the discrimination that they suffered in Mexico. Since Mexico is a member of NAFTA and also has a bilateral FTA with the European Union (EU), the US and the European manufacturing subsidiaries in Mexico enjoy free imports of parts from parent companies. Also, the US and European companies can export finished goods to Mexico without tariffs. Which meant that Japanese companies are subjected to high tariffs.

The rapid development of NAFTA and the EC deepened with the inclusion of former USSR countries in Central and Eastern Europe. Against this setting, Japan increasingly became isolated from trade-favorable treatments received by FTA in North America and Europe which eventually affected its trade advantage. Thus, the need for securing a sustainable new market forced Japan to focus on FTAs with ASEAN members which had already formulated their own ASEAN Free Trade Area (AFTA).

However, Japan's policy towards regionalism shifted with the outbreak of the Asian Financial Crisis in 1997. In reaction to the crisis, ASEAN expected more from Japan in playing a prominent role to mitigate the widespread consequences of the crisis. Initially, Japan's role saw conformity to the demands of the International Monetary Fund (IMF) bail-out packages, which

\footnotetext{
9 Michael Sutton, “Japanese trade policy and 'Economic partnership agreements': a new conventional wisdom," Ritsumeikan Annual Review of International Studies, Vol. 4, pp 113-135, 2005, available at http://www.ritsumei.ac.jp/acd/cg/ir/college/bulletin/e-vol4/sutton.pdf

${ }_{10}$ Michael Sutton, "Open regionalism and the Asia-Pacific: Implications for the rise of an East Asian economic community," Ritsumeikan International Affairs, Vol. 5, pp 133-152, 2007, available at http://www.ritsumei.ac.jp/acd/re/k-rsc/ras/04_publications/ria_en/5-07.pdf

${ }^{11}$ Wong, "China-ASEAN and Japan-ASEAN relations during the post-Cold War era," Chinese Journal of International Politics, Vol.1, pp 373-404, 2013, available at http://www2.jiia.or.jp/en/pdf/publication/201306_005kokusaimondai.pdf

12 Shujiro Urata, “Japan's trade policy with Asia,” Public Policy Review, Vol. 10, Issue 1, p. 21, 2014, available at https://www.mof.go.jp/english/pri/publication/pp_review/ppr024/ppr024a.pdf
} 
included offered assistance of USD 4 billion to Thailand in August and 5 billion to Indonesia. ${ }^{13}$ To the surprise of many, Japan come out with a radical solution by wanting to create an Asian Monetary Fund (AMF) consisting of Japan, China, South Korea, Hong Kong, Singapore, Malaysia, Thailand, Indonesia, Philippines and Australia. The AMF aimed at playing a role in helping affected countries through USD10 billion worth of funds. The AMF proposal, despite objections from the U.S, signified Japan's departure from its traditional priority towards US and Western blocs, by aligning and identifying itself as part of East Asia. ${ }^{14}$ Although this proposal received warm support from ASEAN countries, it failed to materialize, particularly due to opposition from the US and China. For example,

The United States, which saw the AMF as a Trojan horse to undermine its position of dominance; the Chinese, who were suspicious of the Japanese intent behind the proposal; and the IMF, which for institutional and bureaucratic reasons also opposed the AMF as a serious threat to its influence and relevance in the region..$^{15}$

Meanwhile, Japan took further proactive initiative by introducing a new regional financial mechanism through the New Miyazawa Initiative by committing USD30 billion in loans to the East Asian countries affected by the crisis. Brought on by skepticism towards APEC and Western countries failure to tackle the crisis, a sense of regionalism grew among East Asian countries. The change of attitude towards regional cooperation came through the establishment of the ASEAN Plus Three (APT). In contrast to EAEG, the US was willing to accept APT due to its apparent lack of threat. Meanwhile, Japan already had a greater advantage in the region through its cooperation with ASEAN and East Asian countries.

Through the APT Summit in 1999, East Asian countries agreed to support Japan's idea of establishing a regional currency crisis mechanism through the creation of the Chiang Mai Initiative (CMI). The CMI was created explicitly as a regional subsidiary, following the guidelines of the IMF closely by complementing to the existing global regime through the $20 \%$ link to the IMF, and also through the implicit reliance of IMF standards of financial surveillance. ${ }^{16}$ Although earlier APEC was favored by Japan to promote the regionalization process in East Asia, the aftermath of the Asian Financial Crisis diverted this stance. While Japan's unceasing effort to counter the crisis somehow represented its leadership role, the failure of the AMF to materialize also became a diplomatic blow to Tokyo in East Asia. One of the blows received by Japan was China's closeness to ASEAN. During the crisis, China's vital decision of not devaluing its Yuan was welcomed by

\footnotetext{
${ }^{13}$ Emilio de Miguel, "Japan and Southeast Asia: from the Fukuda Doctrine to Abe's Five Principles," UNISCI Discussion Papers, No. 32, 2013, available at https://revistas.ucm.es/index.php/UNIS /article /viewFile/44792/42219

${ }^{14}$ Sueo Sudo, "Japan's ASEAN policy: reactive or proactive in the face of a rising China in East Asia ," Asian Perspective, Vol. 33, Issue 1, pp 137-158, 2009, available at http://crawl.prod.proquest.com.s3.amazonaws.com/fpcache/69220c45733de8443c8b062ff60e4e54.pdf?AWSAccess KeyId=AKIAJF7V7KNV2KKY2NUQ\&Expires=1468867886\&Signature=ildoIsL2852JT6CVAi4X12FY9gs\%3D

${ }^{15}$ Youngwon Cho, "Taking stock of monetary regionalism in East Asia: A glass half-full or half empty?," The Journal of East Asian Affairs, Vol. 27, Issue, 2, p. 61 , 2013, available at http://people.stfx.ca/ycho/\%20publications/Cho,\%20Taking\%20Stock\%20of\%20East\%20Asian\%20Monetary\%20R egionalism.pdf

${ }^{16}$ Evelyn Goh, "East Asian Financial Regionalism and the Renegotiation of Global Economic Order," Studia Diplomatica, p. 5, 2013, available at http://kyspp2.nus.edu.sg/cag/wp-content/uploads/sites/5/\%202013/07/EastAsian-Financial-Regionalism-and-the-Renegotiation-of-Global-Economic-Order-by-Evelyn-Goh.pdf
} 
ASEAN countries and subsequently ASEAN increasingly saw China as a potential leader rather than Japan.

After the financial crisis, the APT framework emerged as the leading mechanism in further promoting regional integration in East Asia. While CMI can be considered the first success under the APT framework, the process of trade liberalization between member countries by aiming for the creation of the East Asia Free Trade Area (EAFTA) was considered another milestone achievement. As mentioned earlier, earlier Japan was not supportive of FTAs but this changed in 2000 when Japan conducted bilateral discussions with Singapore to conclude a FTA. The change in attitude from Japan towards FTA became further strengthened through a speech in 2002 delivered by the then Japanese Prime Minister, Junichiro Koizumi who called for closer relations with ASEAN by the creation of FTA between Japan and ASEAN to promote further economic cooperation across multiple levels. ${ }^{17}$ In respect to the progress of FTA between ASEAN and its partners, the cooperation between ASEAN and Japan seems to move through a slower pace compared to China and South Korea.

Using the APT framework, China in particular has started to promote East Asian integration with ASEAN as its key partner. In 2002, China and ASEAN agreed to finalize the Framework Agreement on Comprehensive Economic Cooperation between ASEAN and China which set up the pattern for future establishment of the ASEAN-China Free Trade Area (ACFTA). In 2005 the Framework Agreement on Comprehensive Economic Cooperation and Agreement on Dispute Settlement Mechanism was signed which includes provisions towards the establishment for the ASEAN-Korea Free Trade Area.

Rapid progress of FTA proliferation between ASEAN and other regional partners was carefully watched by Japan which preferred to conclude bilateral FTA's with specific individual ASEAN members. ${ }^{18}$ Negotiations between ASEAN and Japan became finalized in 2008 through the Agreement on Comprehensive Economic Partnership (AJCEP) which stipulated the establishment of ASEAN-Japan free trade area by 2012. However, Japan did not come out with adequate economic incentives for ASEAN. The establishment of Japan's FTA's with Singapore provided little incentive for ASEAN with the increase on industrial goods export from Singapore while proving to be insignificant in the market of agricultural exports, which is not the major export of the Singaporean economy but for ASEAN countries. Moreover, since Japan was already focusing on bilateral FTAs during earlier years since the Asian Financial Crisis, the AJCEP was expected to play a limited role in the aspect of regional integration. Hence, since tariffs in the ASEAN member individual bilateral trade agreement with Japan are much lower than the regional agreement with Japan, ASEAN countries were more likely to use individual FTAs when trading with Japan but they use AFTA when trading with each other.

China's rapid involvement through the APT process and growing close involvement with ASEAN concerned Japan as it faced declining posture in East Asia. So Japan now prefers the enlargement of another grouping, the East Asian Summit (EAS) beyond the original 13 members of the APT. The formation of EAS was based as a complimentary support to the long term

\footnotetext{
${ }^{17}$ Lai FoonWong, "China-ASEAN and Japan-ASEAN relations during the post-Cold War era," Chinese Journal of International Politics, Vol.1, pp 373-404, 2013, available at http://www2.jiia.or.jp/en/pdf/publication/201306_005kokusaimondai.pdf

${ }^{18}$ Vyacheslav V. Gavrilov, "Framework of the ASEAN Plus Three mechanisms operating in the sphere of economic cooperation," Cale Discussion Paper, No. 7 (2011), available at http://cale.law.nagoyau.ac.jp/_src/sc597/CALE20DP20No.207-110826.pdf
} 
objective of the existing APT process. The critical argument centered on EAS membership. The main issue was as follows,

Differences over membership saw Japan, Indonesia and Singapore calling for the inclusion of Australia, New Zealand and India into the summit, while China and Malaysia strongly opposed this on the grounds that the entry of "extra regional" actors would dilute the putative identity and purpose of the APT. ${ }^{19}$

Japan's promotion of the inclusion of Australia and New Zealand which shared similar visions regarding East Asia into EAS were partially motivated by the need to reduce China's influence and assertiveness towards ASEAN, and at the same time prevent the APT from becoming closed and an inward grouping against Europe and North America (Guan, 2011). Although Japan's push for EAS membership expansion divided ASEAN members but they managed to find common a ground to support this development. The rapid involvement of China through ASEAN regional institutions, particularly the APT created fear of Chinese domination. In order for ASEAN to preserve its relevancy in East Asia, it must play a central role in the regionalization process in East Asia. Understanding this, the ASEAN Foreign Minister's Meeting in 2005 decided to identify the standard requirements for EAS memberships which included having substantial relations with ASEAN, including full dialogue partner status and being a signatory to the Treaty of Amity and Cooperation (TAC) ${ }^{20}$ This assured ASEAN the greatest share of the role in EAS through which any important decisions relating to participation in the grouping is exclusively determined by ASEAN.

In response, Japan's Ministry of Foreign Affairs (MOFA) in the APT Foreign Ministers Meeting 2005 acknowledged ASEAN's concerns and agreed that the entity should retain its leadership position in the process of East Asian regionalism, while voicing the need for EAS cochairmanship and future possibilities for EAS to be conducted outside of ASEAN.$^{21}$ In relation to the issue of membership, Japan also used the EAS mechanism to further enhance its influence, notably through its proposal for its own regional economic integration approach, namely the Comprehensive Economic Partnership Agreement (CEPEA). The CEPEA's objective was to create FTAs including all members of EAS. This was a direct challenge from Japan towards the EAFTA idea which was endorsed by China through the APT mechanism. The CEPEA includes jurisdiction of rules of investments, human-capital transfers and protection of intellectual properties. At the same time, CEPEA membership is obviously larger compared to the EAFTA. Hence, this is expected to bring much greater economic potential to the member countries.

Through the EAS, Japan also initiated a research institute to support the EAS integration process. The so called Economic Research Institute for ASEAN and East Asia (ERIA) reflects Japan's commitment to facilitate economic integration with ASEAN as a key partner. The creation of this body reflects the similar role played by the Network of East Asian Think Tanks under the APT process. Japan made a huge commitment through its large funding of approximate USD 100 million for a 10-year period in comparison with its fund of USD 900000 for the APT Cooperative

\footnotetext{
${ }^{19}$ Deepak Nair, "Regionalism in the Asia Pacific/East Asia: A frustrated regionalism," Contemporary Southeast Asian Economies, Vol. 31, Issue 3, p. 119, 2009.

${ }^{20}$ Sheldon Simon, "ASEAN and multilateralism: the long, bumpy road to community," Contemporary Southeast Asia, Vol. 30, Issue 2, pp 264-292, 2008.

${ }^{21}$ Benny Cheng Guan Teh, "Japan-China Rivalry: What role does the East Asia Summit play?," Asia Pacific Viewpoint, Vol. 52, Issue 3, pp 347-360, 2011.
} 
Fund in 2008. ${ }^{22}$ In addition, while Japan has continues to support towards the RCEP, it is also currently a member of the TPPA together with another four ASEAN countries which are Malaysia, Singapore, Brunei and Vietnam. While Japan maintained its support for a wider Asia Pacific regional cooperation, it is also evident that Tokyo wants to secure better arrangement in sensitive sector of TPP such as the domestic agricultural market by playing the 'China Card' against the $\mathrm{US}^{23}$

\section{Japan's and ASEAN Integration}

In a similar manner to the EU, ASEAN over time has grown from the initial five founding members to become an organization of 10 countries. In the long run, although ASEAN now faces challenges to unite all its members, nevertheless this development has further enhanced ASEAN's credibility since it can now project more influence in East Asia. Inspired by regionalism dynamics in Europe and North America, ASEAN agreed to the establishment of the ASEAN Free Trade Area (AFTA) in 1992 and the inclusion of Indochinese countries of Vietnam (1995), Myanmar (1997), Laos (1997), and Cambodia (1999) in the post-Cold War era. ASEAN now shows visible divide of economic and wealth inequality between its members. Hence, ASEAN's main focus now is to deepen and integrate the economies of its different members into forming a single market and production base.

As discussed earlier, Japan's economic policies towards ASEAN since 1977 has led its corporations to invest and establish productions base in ASEAN. Thus, Japan has immensely contributed to the first step of ASEAN Community through the trans-regional production network across Southeast Asia. The creation of AFTA seeks to facilitate trade liberalization by reducing tariffs on intra ASEAN trade to $0-5 \%$, and later to achieve zero elimination of all tariffs. In line with supporting the ASEAN policy, Japan as ASEAN's major economic partner has played a leading role in assisting the AFTA formation.

In 1992, the ASEAN Economic Ministers (AEM) and the Japanese Ministry of International Trade and Industry (MITI) began to hold meetings - AEM-MITI on the fringe of AEM meetings to share views on economic issues and discuss specific areas for cooperation. MITI held a series of seminars on the AFTA in a confidence building effort between ASEAN and Japanese investors. MITI also provided a range of development advice to ASEAN policymakers. ${ }^{24}$ Although in general, Japan's reception towards the proposed establishment of AFTA has been supportive, it failed to engage in any trade preferential agreements with ASEAN. ${ }^{25}$ As a matter of fact, Japan rather include preferential trading agreement under the multilateral WTO and GATT frameworks. However, by the late 1990s there was a sudden change to prioritize the Regional Trade Agreements. As discussed earlier, Japan's policy of working under multilateral frameworks like GATT and subsequently the WTO has faced numerous obstacles.

\footnotetext{
22 Ibid.

23 Shintaro Hamanaka, "Trans-Pacific Partnership versus Regional Comprehensive Partnership: control of membership and agenda setting," ADB Working Paper Series on Regional Economic Integration, No. 146, 2014, available at https:/www.adb.org/sites/default/files/publication/152753/reiwp-146.pdf

24 Naoko Munakata, "Evolution of Japan's Policy toward Economic Integration," Working Paper (Brooking Institution, 2001), https://www.brookings.edu/wp-content/uploads/2016/06/2001_munakata.

${ }^{25}$ Shujiro Urata, "Japan's trade policy with Asia," Public Policy Review, Vol. 10, Issue 1, p. 21, 2014, available at https://www.mof.go.jp/english/pri/publication/pp_review/ppr024/ppr024a.pdf
} 
To further integrate ASEAN members, the formation of the ASEAN Community was envisioned in 2003 based on three pillars; economics, politics and security and socio-cultural dimensions. As a strategy to achieve the vision of building the ASEAN Economic Community, 'Master Plan on ASEAN Connectivity' was adopted in 2010 as the key official framework to build a well-connected ASEAN with the help of its partners comprising three different components which were; physical connectivity, institutional connectivity and people to people connectivity. Enhancing ASEAN Connectivity by, for example, maintaining road networks (physical connectivity) and eliminating non-tariff barriers in trade and investment (institutional connectivity) is integral to further building the ASEAN Community since a well-connected ASEAN will facilitate the flow of goods and people and contribute towards a more competitive and resilient region. ${ }^{26}$

Japan's commitment towards supporting ASEAN Connectivity came right after ASEAN leaders agreed on the Master Plan on ASEAN Connectivity through the announcement of the 'Initial Plan for Cooperation on ASEAN Connectivity' during the $13^{\text {th }}$ ASEAN Japan Summit in 2010. Japan also emerged as one of the earliest partners to develop a joint committee with ASEAN while coming out with the plan of 'Japan Vision for Supporting ASEAN Connectivity' which comprised of two visions; 'Formation of the Vital Artery for East-West and the Southern Economic Corridor' and 'Maritime ASEAN Economic Corridor'. ${ }^{27}$ Japan's East West Economic Corridor vertically included Vietnam, Laos, Thailand and Myanmar. Its starting point was at Da Nang, Vietnam while ending in Mawlamyaing, Myanmar. Its "Southern Economic Corridor" meanwhile connects major economic areas across the Mekong region. Similarly the "Maritime ASEAN Economic Corridor" targets aims to consolidate connectivity through development in port areas, power and ICT in Malaysia, Singapore, Brunei, Indonesia and Philippines.

From year to year, Japan has steadily extended its contribution towards ASEAN's Connectivity program particularly in physical connectivity. From 2011 onwards, the list of Japansese 'Flagship Projects' has totaled of 32. During the ASEAN-Japan Commemorative Summit in 2013, Japan added a new list of connectivity projects which toltlled $70 .{ }^{28}$ Former Minister for Foreign Affairs of Japan, Fumio Kishida while giving a speech in Thailand, emphasized that Japan's efforts in enhancing connectivity in ASEAN through physical development such as roads, bridges, and railways will bring greater benefit through the facilitation of flow of people and goods in the respective economic corridor. ${ }^{29}$ The evidence for his speech was the construction of the second Mekong International Bridge, which greatly helped in shortening the duration of transportation of people and goods between Hanoi and Bangkok from 2 weeks by sea route to 3 days through land access. The positive impact related to cost reductions and time saving in facilitating greater economic activities in both areas. ${ }^{30}$

In analyzing Japan's contributions in narrowing the development gap in ASEAN, it has always put a priority in developing the Mekong region in particularly through the aspect of

26 Mission of Japan to ASEAN, Japan's Cooperation on ASEAN 2025, 2016, available at https://www.brookings.edu/wp-content/uploads/2016/06/2001_munakata.

27 JICA, JICA's Regional Cooperation in ASEAN, 2012, available at https://www.jica.go.jp/english/publications/brochures/c8h0vm0000avs7w2-att/jica_asean.pdf

28 Mission of Japan to ASEAN, Japan's Cooperation on ASEA $\bar{N}$ 2025, 2016, available at https://www.brookings.edu/wp-content/uploads/2016/06/2001_munakata.

${ }^{29}$ MOFA, ASEAN policy speech "Diversity and connectivity-role of Japan as a partner” by H.E. Mr. Fumio Kishida Minister for Foreign Affairs of Japan, 2016, available at http://www.mofa.go.jp/a_o/rp/page4e_000424.html

30 JICA, JICA's Regional cooperation in ASEAN, 2012, available at https:/www.jica.go.jp/english/publications/brochures/c8h0vm0000avs7w2-att/jica_asean.pdf 
physical connectivity. By acknowledging addressing the development gap between the Mekong region located countries with the other ASEAN members, Japan placed considerable importance in delivering high quality and sustainable development to the Mekong region. During the Seventh Mekong-Japan Summit in 2015, a new plan called the "New Tokyo Strategy 2015 for MekongJapan Cooperation" was adopted. The new plan aimed at realizing the ASEAN Community through four elements which were strengthening the quality of growth by promoting quality infrastructure in the region, enhancing 'soft connectivity' by supporting development of institutions, focusing on sustainable developments and coordinating with various stakeholders. ${ }^{31}$ Under the main principle in realizing the 'quality growth' in ASEAN, Japan offered monetary support amounting to 750 billion yen of Official Development Assistance (ODA) over three years and encouraged private-sector investment and enhancing public-private partnerships. ${ }^{32}$ Furthermore, Prime Minister Abe recently announced the 'Partnership for Quality Infrastructure: Investment for Asia's Future' in May 2015 which aimed to promote "quality infrastructure investment" in pursuit of "quality as well as quantity", in collaboration with other countries, international organizations including the Asian Development Bank (ADB) and other financial institutions, expected to further enhance the developmental in the Mekong region. ${ }^{33}$

Apart from physical connectivity, Japan has also contributed towards strengthening institutional connectivity in ASEAN. In order to nurture strong economic growth, legal and judicial systems should need to be strengthened. Japan's involvement in institutional building has created positive developments in the legal systems, which included economic and business laws enhancement in the Mekong region. To promote a broader form of regional cooperation through cross border flow of goods, Japan proposed the concept of an 'Asia Cargo Highway' which is to be realized by 2020. To achieve this aim, Japan continues to cooperate with ASEAN to facilitate trade activities which includes modernizing customs regulations in the Mekong region. ${ }^{34}$

\section{ASEAN and China in Regional Cooperation}

China's earlier response towards cooperation has been fueled by lack of trust towards regional multilateral forums. This attitude has been driven by China's perception of possible challenges that may arise from multilateral diplomacy pertaining to the issue of its national interest, in particularly regarding its claim over the South China Sea. At the same time, the intensification of the South China Sea dispute with China from 1994 to 1996 has further exacerbated ASEAN China relations. Thus, ASEAN countries' central aim in establishing the ASEAN Regional Forum (ARF) was to regulate China's behavior and encourage it to become a responsible actor. ${ }^{35}$

Economically, China has never put forth a serious regional trade policy towards ASEAN before the year 2000. The negotiations to resume position as the original contracting party of GATT and to obtain WTO membership became the main focus of China in the first and the second

\footnotetext{
31 Mission of Japan to ASEAN, Japan's Cooperation on ASEAN 2025, 2016, available at https://www.brookings.edu/wp-content/uploads/2016/06/2001_munakata.

${ }^{32}$ Mission of Japan to ASEAN, Japan's Cooperation towards the AEC, 2015, available at http://www.asean.embjapan.go.jp/documents/20151002.pdf

${ }_{33}$ MOFA, ASEAN policy speech "Diversity and connectivity-role of Japan as a partner” by H.E. Mr. Fumio Kishida Minister for Foreign Affairs of Japan, 2016, available at http://www.mofa.go.jp/a_o/rp/page4e_000424.html

34 JICA, JICA's Regional Cooperation in ASEAN, 2012, available at https://www.jica.go.jp/english/publications/brochures/c8h0vm0000avs7w2-att/jica_asean.pdf

35 Jeannie Henderson, Reassessing ASEAN (London: Oxford University, 1999).
} 
decades before $2000 .{ }^{36}$ Given China priority towards global level cooperation, trade value with ASEAN remained low and slow in growth during this period. In the past decade and a half, China as an "international workshop" and "the black hole of foreign investment" has sometimes been seen as developing at the expense of ASEAN. This is true as Chinese exports reduced ASEAN's share of international market access, and greater investment funds flowing into China reduced those flowing into ASEAN. As Chinese economy continues to expand, it will act as further threat towards ASEAN. As ASEAN countries relying on an export-oriented economic policy, eventually Chinese growing economic dominance would outpace ASEAN through its comparative advantage in labor and manufacturing costs. Moreover, if ASEAN countries lose out and are less stable to investors, this may shift further investment flow towards China. ${ }^{37}$

In its earlier years of participation in APEC, China strongly supported ASEAN's opposition against the trade liberalization push by the US and Western nations. China viewed APEC as one of the US tools to gain access over domestic market access in Asian countries. Facing potential dominance by the US, instead of pushing for trade and investment liberalization, China and ASEAN leaders argued that strengthening economic and technical cooperation should be given priority while taking into account principles of sovereignty and nonintervention. During the Bogor Declaration in 1994, China and ASEAN achieved agreement over preferred form of cooperation through respect, consensus and maintaining APEC as a discussion platform rather than a negotiating platform.

The failure of APEC to react and respond effectively during the Asian Financial Crisis in 1997 provided China with the opportunity to enhance relations with ASEAN by showing its commitment in assisting regional economic growth. In particular, Chinese efforts not to devalue the Renminbi helped to keep ASEAN countries' export competitive internationally. China also played a central role in the formation of the Chiang Mai Initiative (CMI) and subsequently the Chiang Mai Initiative Multilateralization (CMIM) to assist member states who were facing short term liquidity problems. Bilateral swap agreement through the CMIM allowed China to internationalize the use of Renminbi with ASEAN to especially in trade and investment.

On the other hand, the scale and contagion of the crisis also created a new reminder for China to actively participate and develop regional economic cooperation. This factor has driven the shift of China's foreign economic policy from multilateralism towards promoting regional FTAs. The agreement over establishment of the ACFTA in 2002 which stipulated a flexible time framework for ASEAN different members resulted in only from $40 \%$ of goods subjected to a reduction in tariffs to $5 \%$ or less. Though the accord broadened the range of goods to $60 \%$ of imports within two years, but the agreement also incorporated many exceptions for sensitive products.

Apart from permitting ASEAN to be protective of its trading goods, China also showed its flexibility by allowing agricultural imports from ASEAN countries into its own domestic market. Over the year China managed to reduce its tariff on rice imports, sugar, vegetable oils, poultry and seafood products. For ASEAN countries that depend heavily on agricultural exports, China's decision was seen as beneficial as it substituted traditional markets of the US and Japan which had stricter rules.

\footnotetext{
${ }^{36}$ Liqin Wang, "Is China a trade competitor of ASEAN? A Chinese perspective on the proposing, cultivation and implications of the CAFTA," Journal of Contemporary Eastern Asia, Vol. 10, Issue 2, p. 123, 2011b, available at http://eastasia.yu.ac.kr/documents/Wang_10_2.pdf

${ }^{37}$ Christopher Napoli, "China's economic rise: implications for ASEAN trade Flows," Journal of Southeast Asian Economies, Vol. 31, Issue 3, pp 345-360, 2014.
} 
How did China became so willing to open its domestic market towards exports from ASEAN? The reason has its root in China's participation in the WTO which has left them with little option but to comply with the terms imposed by the organization. Analysis found that during the fifteen years of the negotiation period, China liberalized its trade with $15 \%$ of tariff leveled down, and most of the import quotas and licenses were also dismantled. Ultimately, China's economic liberalization allowed itself to become more proactive in negotiations over liberalization of trade in goods and services in FTA negotiations in comparison with ASEAN members. When giving ASEAN favorable treatment over China's domestic market, Beijing faced trade deficits with ASEAN amounting to USD 40 billion in 2011.38 One particular explanation for this is, as Chinese domestic supply base grew significant, its reliance over ASEAN supply for parts and intermediate products became reduced.

China found the ASEAN Plus Three arrangement highly satisfactory and the exclusion of the US as a major win. The fact that it emerged partly as an outcome of dissatisfaction with the IMF and APEC was interpreted as a decline in US influence in the region. Growing differences between China and Japan over the shape of regional mechanism to integrate East Asian economies has slowed the push for China's initiative. This development eventually led ASEAN to propose the establishment of the RCEP in 2011. The RCEP's objective was to act as a mechanism to harmonize the existing FTA's framework agreements based on the ASEAN Plus One mechanism. However, while ASEAN has materialized FTA agreements with China, Japan, Korea, AustraliaNew Zealand and India, some other countries such as China and Japan, and Japan and Korea did not have an FTA agreement with each other. This deficiency has created a major obstacle to the realization of a single wider FTA in East Asia.

Zhang and Shen remark that "China shows its high interest to RCEP since it made lots of effort on consolidating the overlapping FTAs by leading the EAFTA study and initiating the joint proposal with Japan". ${ }^{39}$ Difficulties in negotiations between China, Japan and Korea (CJK) FTA remains due to sensitive issues like the agriculture sector. For Japan and Korea, in contrast to China which has a comparative advantage in the agriculture sector, this particular issue remains a major obstacle to the establishment of a regional wide FTA. On the other hand, China face a lack of comparative advantage in medium and high technology industries.

China seems to be cooperative over the negotiations of the establishment of a trilateral CJKFTA. The reason for this can be based on the previous US proposed TPPA under the APEC framework. China has been excluded from the TPPA negotiations and the possibilities of inclusion of the US into an integrated East Asian economy would lessen China's influence in the grouping. On the other hand, by supporting ASEAN Centrality or ASEAN's leading role in RCEP, China can exclude the participation of the US since the requirement of membership is based on ASEAN Plus 1 FTA in which the US have yet to establish an FTA with ASEAN.

China has immensely supported ASEAN's leading role in regional cooperation. Nevertheless, China appears to react differently towards ASEAN's role in different regional multilateral forums. While China has adhered to back ASEAN as the regional main driver in economic cooperation such as the APT and RCEP, Beijing's voice is different in political and security issues such as the South China Sea dispute. ASEAN's role to act as facilitator over the

\footnotetext{
${ }^{38}$ Yuning Gao and Junyi Zhang, "Emerging China and its interaction with ASEAN Economies," In Chinese Global Production Networks in ASEAN, ed. Kim Young Chan (London: Springer, 2016), pp 1-18.

39 Zhang Yunling and Shen Minghui, "FTAs in the Asia-Pacific: a Chinese Perspective," Kokusai Mondai (International Affairs), p.8, 2013, available at http:/www2.jiia.or.jp/en/pdf/publication/2013-06_005kokusaimondai.pdf
} 
dispute has been rejected by China as it insists on discussing bilaterally between claimant countries. Thus, ASEAN's position in viewing China as a central actor in regional cooperation depends whether both China's and ASEAN's interests intersect or not.

Recently, China has begun to seek a greater role in regional cooperation through its One Belt, One Road initiative and the Asian Infrastructure Investment Bank (AIIB). While it does not explicitly challenge the current institutions in East Asia, it represents China's real attitude towards ASEAN's leading role. China views ASEAN's leading role in a particular context through the lack of concrete achievement in the regionalism process and the existing dispute between China and some ASEAN members which causes hindrance in deepening bilateral cooperation.

\section{China and the ASEAN Economic Community}

ASEAN agreed to the adoption of the Master Plan on ASEAN Connectivity in 2010 which gives specific focus towards improving physical connectivity among ASEAN countries in order to achieve broader economic integration in realizing AEC by 2015. One of the major hindrances towards financing an adequate and integrated system of infrastructure in ASEAN is the difficulties of finding funding. Infrastructure development in ASEAN in part has been maintained by using Chinese investment funds. China established the Silk Road Fund with USD40 billion financial capital to support the Belt and Road initiative which focuses on infrastructure projects that can improve regional connectivity, while the USD1 billion funded China-ASEAN Cooperation Investment Fund (CAF) targets to financing investment projects through equity deals. ${ }^{40}$

In 2013, China's Finance Ministry proposed the establishment of the AIIB to provide fund for capital construction of infrastructure projects in developing countries within Asia. Although the proposal of AIIB was opposed by US, particularly for fear of adverse effects on existing institutions, the popularity of AIIB has lessened US opposition to AIIB. In this regard, AIIB emphasizes promoting regional interconnectivity and integration but at the same time 'cooperating with existing multilateral development banks'. ${ }^{41}$ China's AIIB initiative which is participated by all ASEAN members is expected to finance key infrastructure development projects in ASEAN that were identified through the Master Plan of ASEAN Connectivity such as the Singapore Kunming Rail Link. There is fear that the AIIB fund will hinder rather than promote ASEAN connectivity as member countries are competing with each other for infrastructure funding. ${ }^{42}$ Among the top priorities of the Master Plan on ASEAN Connectivity is the completion of the Singapore Kunming Rail Link connecting China with ASEAN. The Singapore Kunming Rail Link network offers opportunities of infrastructure building such as roads and bridges in ASEAN countries. The project will help integrate ASEAN to the network of ports between China and Southeast Asia. The construction of the high speed railway is expected to not only contribute to the intra ASEAN connectivity but also extend to East Asian integration. As part of the Trans-Asian

\footnotetext{
${ }^{40}$ Inclusive Development International, Making inroads: Chinese infrastructure investment in ASEAN and beyond, 2016, available at http://www.inclusivedevelopment.net/wp-content/uploads/2016/08/Making-Inroads-ChinaInfrastructure-Finance.pdf

${ }^{41}$ AIIB, History of AIIB, 2016, available at http://www.aiib.org/html/aboutus/introduction/history/?show=0

42 Sanchita, "Can the China-led AIIB support the ASEAN connectivity master plan?," ISEAS Perspective, No. 30, 2015, available at https://www.iseas.edu.sg/images/pdf/iseas_perspective_2015_30.pdf
} 
Railway network, the high speed trains will be extended to the west of Iran, Singapore in the south, Xiamen and Shanghai in coastal China and to the Chengdu, China in the North. ${ }^{43}$

China has heavily invested in the North South Economic Corridor plan which connects Kunming in Southern China to Mainland Southeast Asia under two developmental routes. The corridor starts at Kunming, Yunnan and ends at Hanoi, forming a coastal economic development line. On the other hand, another road was constructed to connect Kunming with Bangkok forming an inland economic zone. Hence the North South Economic Corridor strategically connects major cities in mainland Southeast Asia, which in the end will create economic benefits to ASEAN members. The plan also identified the intra-ASEAN connectivity in maritime Southeast Asia by encouraging the enhancement of improved reliability and efficiency of ASEAN ports. At the same time, most of the gateway ports of the ASEAN member states are already "fairly full" which means that investments in capacity expansion would have to be made in order to meet the growth in trade expected from the deeper economic integration of the ASEAN states among themselves and with the rest of the world.

Notably, China's effort towards promoting ASEAN connectivity through infrastructure investments has been prioritized particularly within the CLMV countries to the south of its provinces Yunnan and Guangxi. Dubbed as 'Bridgehead Strategy', the investments in mainland Southeast Asia has been spearheaded by Yunnan province itself while 'One Axis, Two Wings' of the economic corridor investment strategy has been pursued by Guangxi province. ${ }^{44}$ Rationally, while economic relations of ASEAN - China have shown positive growth in recent years, there are striking contradictions of the unequal share of economic engagement between China and ASEAN states.

Although China's direct borders with ASEAN are limited to Vietnam, Laos and Myanmar, most of the trade share occurs with Malaysia, Singapore and Thailand through ocean shipping. The strategic location of the CLMV countries allows China to pursue its own 'Two Ocean Strategy' by linking China to India or connecting the Indian Ocean to the Pacific Ocean, which acts as a bridge in integrating different market access wthin China, ASEAN and South Asia. Therefore, the Yunnan province in particular, is critical in China's strategy to build well connected transportation hubs that link China to ASEAN. Other than that, China's commitment towards development of connectivity in the mainland corridor has allowed gradual economic progress in relations with the increase in bilateral trade performances and bilateral trade cost reductions between China and mainland ASEAN rather than that of maritime states.

\section{Analysis}

The relationship between ASEAN and China became prominent after the Asian Financial Crisis in 1997, when ASEAN's relations with Japan faced stagnancy with Tokyo's lack of leadership in pushing for cooperation with ASEAN. However, Japan has since become more active in stepping up its role against China's engagement with ASEAN. In this essay, discusses the characteristics of Japan's responses towards Chin'sa economic incentives and initiatives and factors that influenced Japan's decisions. Based on the analysis, Japan's responses towards China's economic

\footnotetext{
43 Neala Menz, "China-ASEAN high-speed rail project," The Undergraduate Review, Vol. 8, pp 135-135, 2012, available at http://vc.bridgew.edu/cgi/viewcontent.cgi?article=1226\&context=undergrad_rev

44 Geoff Wade, "ASEAN divides," New Mandala, available at http://www.newmandala.org/wpcontent/uploads/2010/12/Wade-ASEAN-Divides.pdf
} 
initiative and incentives towards ASEAN can be grounded on 3 different dimensions which are regional integration, supporting ASEAN connectivity and promoting closer strategic partnerships in various fields with ASEAN.

\section{Regional Integration}

Japan's push for the AJCEP agreement with ASEAN came as a direct response towards China's initiative to negotiate the establishment of bilateral FTAs with ASEAN. Japan's enthusiasm in upgrading its economic relations through a trade liberalization plan with ASEAN was hugely shaped by the pressure to react towards China's expanding relations with ASEAN. Instead of promoting closer economic cooperation with ASEAN, Japan placed priorities to negotiate FTAs on bilateral grounds, through which can help prevent reduction of tariffs for its own sensitive agricultural sector. On the other hand, the China ACFTA initiative gave ASEAN a central role from which the AFTA framework was to be implemented within the ACFTA agreement. To counter this plan, Japan promoted broader roles of economic cooperation such as liberalization of services, movement of labour, intellectual property, investments and technical cooperation in the AJCEP.

Chinese and Japanese rivalry became the major theme in the process of formulating region-wide FTA with their own respective proposals of EAFTA and CEPEA through ASEANled institution. China's EAFTA proposals emphasized on economic benefits by harmonizing established network of agreements between ASEAN and its partners through the APT process, while Japan's CEPEA initiative centered on EAS to promotes the enlargement of trade networks with the inclusion of Australia, New Zealand and India. In regards to EAFTA, the availability of an established network makes the proposal more feasible and practical over CEPEA, however Japan's emphasis on building greater trade creation through expanding membership has the potential to bring more gains for ASEAN.

\section{ASEAN Connectivity}

China's collaboration in enhancing ASEAN Connectivity has given special focus towards investment in developing large scale transportation infrastructure projects in mainland ASEAN. Transportation networks such as road, railways and ports are being developed according to China's economic corridor strategy which are the One Belt One Road Initiative, Maritime Silk Road and North-South Economic Corridor in order to increase the interconnectivity between China and ASEAN frontier areas especially the CLMV countries. To achieve the infrastructure investment targets, China has set up various financial institutions such as the AIIB, China-ASEAN Infrastructure Investment Fund and the Silk Road Fund.

In response, Japan has expanded its cooperation of investment into infrastructure projects in ASEAN which is demonstrated by providing development assistance to the infrastructure projects such as the East-West Economic Corridor, Southern Economic Corridor and Maritime Economic Corridor. Japan is putting bigger concentration of its infrastructure investments in the CLMV areas left out by China's economic strategies thus ensuring comprehensive development between ASEAN members. Instead of focusing on large scale projects, Japanese investments are promoting intra-ASEAN connectivity between mainland ASEAN and its maritime counterparts. Apart from the participation of investments through the ADB, Japan also has ventured on its own 
'Partnership for Quality Infrastructure' initiative as a means to finance investment projects by emphasizing on sustainability and quality.

\section{Strategic Partnerships}

Since the Joint Declaration on Strategic Partnership for Peace and Prosperity between ASEAN and China took place in 1997 where both parties agreed to promote regional peace and stability while strengthening economic cooperation, China's approach towards promoting closer relations with ASEAN has strongly emphasized the economic aspect. This pattern has been reinforced through China's initiative called the ' $2+7$ cooperation framework' which highlights the call for the advancement of economic cooperation between ASEAN and China through the ACFTA, and the improving of infrastructure connectivity.

In the wake of China's strategic approach through economic cooperation with ASEAN, Japan adopted a different strategy based on promoting universal norms. In 2013, which marked the 40th year of ASEAN Japan Friendship and Cooperation, Japan outlined 'Five Principles' of ASEAN Japan Diplomacy among which the first principle gives priority to cooperation and promotion of universal values such as freedom, democracy, and human rights with ASEAN. In the same framework, Japan also stressed on the rule of law and further promotion flow of trade and investments in economic cooperation with ASEAN. Thus, while economic cooperation remains essential in Japan's approach towards partnering with ASEAN, Tokyo has complimented the cooperation through promoting universal norms and values.

\section{Conclusion}

Japan's response to China's economic initiatives and incentives towards ASEAN have been approached through three fundamental aspects which are regional integration, ASEAN connectivity and strategic partnerships. These responses also represent Japan's interest towards ASEAN in regards to promoting deeper integration and enhancing ASEAN stability as an institution which would later help to secure Tokyo's own future economic and political interests. While economic cooperation still plays a fundamental role in Japan's engagement with ASEAN, it has been supplemented with cooperation in other aspects such as promoting universal values. This will not only counter- balance China's growing influence but at the same time the approach will equally assist to enhance Tokyo's image as sincere in cooperating with ASEAN on the basis of equal partnership outlined under the Fukuda Doctrine.

\section{References}

AIIB, 2016. History of AIIB. http://www.aiib.org/html/aboutus/introduction/history/?show=0 ASEAN. 2011. Master plan on ASEAN connectivity. Jakarta: ASEAN Sekretariat. http://www.asean.org/storage/images/ASEAN_RTK_2014/4_Master_Plan_on_ASEAN_Connect ivity.pdf

Chirathivat, S. 2008. China's rise and its effect on ASEAN-China trade relations. In Goh, E. \& Simon, S.W.S. (eds.). China, the United States, and Southeast Asia; Contending perspectives on politics, security, and economics, pp. 38-55. Oxon: Routledge.

Cho, Y. 2013. Taking stock of monetary regionalism in East Asia: A glass half-full or half empty?

The Journal of East Asian Affairs. 27(2). 55-88. http://people.stfx.ca/ycho/ 
publications/Cho, $\% 20$ Taking\%20Stock\%20of\%20East\%20Asian\%20Monetary\%20Regionalism .pdf

De Miguel, E. 2013. Japan and Southeast Asia: from the Fukuda Doctrine to Abe's Five Principles. UNISCI Discussion Papers No. 32. https://revistas.ucm.es/index.php/UNIS /article /viewFile/44792/42219

Gao, Y. \& Zhang, J. 2016. Emerging China and its interaction with ASEAN economies. In Kim, Y. C. Chinese Global Production Networks in ASEAN, pp.1-18. London : Springer International Publishing.

Gavrilov, V.V. 2011. Framework of the ASEAN Plus Three mechanisms operating in the sphere of economic cooperation. Cale Discussion Paper No. 7. Nagoya University. http://cale.law.nagoya-u.ac.jp/_src/sc597/CALE20DP20No.207-110826.pdf

Goh, E. 2013. East Asian financial regionalism and the renegotiation of global economic order. Studia Diplomatica http://kyspp.nus.edu.sg/cag/wp-content/uploads/sites/5/ 2013/07/EastAsian-Financial-Regionalism-and-the-Renegotiation-of-Global-Economic-Order-by-EvelynGoh.pdf

Guan, B, T. C. 2011. Japan-China rivalry: What role does the East Asia Summit play? Asia Pacific Viewpoint, 52 (3): 347-360.

Hamanaka, S. 2014. Trans-Pacific Partnership versus Regional Comprehensive Partnership: control of membership and agenda setting. ADB Working Paper Series on Regional Economic Integration No. 146, December. http://www.adb.org/sites/default/files/ publication/152753/reiwp146.pdf

Henderson, J. 1999. Reassessing ASEAN. London: Oxford University

Inclusive Development International. 2016. Making inroads: Chinese infrastructure investment in ASEAN and beyond. Asheville, NC : IDI. http://www.inclusivedevelopment.net/wpcontent/uploads/2016/08/Making-Inroads-China-Infrastructure-Finance.pdf

JICA. 2012. JICA's Regional Cooperation in ASEAN, November. http://www.jica.go.jp/english/publications/brochures/c8h0vm000000k9k0-att/jica_asean.pdf

John Wong. 2015. China's "One Belt, One Road" initiative: economic diplomacy with Chinese characteristics. Silk Road Forum 2015.

Kawai, M., Thuzar, M. \& Hayton, B. 2016. ASEAN's Regional Role and Relations with Japan; The Challenges of Deeper Integration. Research Paper from Conference of Chatham House on 22 February 2016. https://www.chathamhouse.org/sites/files/chatham house/publications/research/2016-02-18-asean-regional-role-kawai-thuzar-hayton.pdf

Mearsheimer, J.J. 2010. The Gathering Storm: China's Challenge to US Power in Asia. The Chinese Journal of International Politics. 3(2). 381-396. http://china.prague summerschools.org/ files/china/3china2012.pdf

Menz, N. 2012. China-ASEAN high-speed rail project. The Undergraduate Review 8. 135-138. http://vc.bridgew.edu/undergrad_rev/vol8/iss $1 / 24$

Mie, O. 2014. Challenges to the New ASEAN-Japan Partnership in the Changing Regional Circumstances. Discuss Japan-Japan Foreign Policy Forum No. 20 http://www.japanpolicyforum.jp/pdf/2014/no20/DJweb_20_dip_02.pdf

Minister of Foreign Affairs of the People's Republic of China. 2014. Remarks by H.E. Li Keqiang premier of the state council of the People's Republic of China at the $17^{\text {th }}$ ASEAN China summit. http://www.fmprc.gov.cn/mfa_eng/zxxx_662805/t1212266.shtml 
Minister of Foreign Affairs of the People's Republic of China. 2016a. Wang Yi : step towards a closer China-ASEAN community of common destiny. http://www.fmprc.gov.cn/mfa_eng/ zxxx_662805/t1384891.shtml

Minister of Foreign Affairs of the People's Republic of China. 2016b. Five features of Lancang Mekong river cooperation. http://www.fmprc.gov.cn/mfa_eng/zxxx_662805/t1349239.shtml

Minister of Foreign Affairs of the People's Republic of China. 2011. Speech by H.E. Ambassador Tong Xiaoling at the forum in commemoration of the $20^{\text {th }}$ anniversary marking dialogue relations between China-ASEAN. http://www.fmprc.gov.cn/mfa_eng/ wjb_663304/zwjg_665342/zwbd_665378/t837941.shtml

Mission of Japan to ASEAN. 2015.Japan's cooperation towards the AEC, September. http://www.asean.emb-japan.go.jp/documents/20151002.pdf

Mission of Japan to ASEAN. 2016. Japan's cooperation on ASEAN 2025 (Connectivity), May. http://www.asean.emb-japan.go.jp/asean2025/jpasean-ec03.html

MOFA. 2013. Factsheet on Japan-ASEAN Relations. http://www.mofa.go.jp/region/asiapaci/asean/factsheet.html

MOFA. 2016. ASEAN policy speech "Diversity and connectivity - role of Japan as a partner" by H.E. Mr. Fumio Kishida Minister for Foreign Affairs of Japan, May. http://www.mofa.go.jp/a_o/rp/page4e_000424.html

MOFA.2007. Joint Statement in conjunction with the 50th Anniversary of Japan-Malaysia diplomatic relations "Everlasting friendship and far-reaching partnership: towards a common future", August. http://www.mofa.go.jp/region/asia-paci/pmv0708/joint-4.html

Munakata, N. 2001. Evolution of Japan's policy toward economic integration, Working Paper, Brooking Institution, December. http://www.brookings.edu/fp/cnaps/papers/2001_munakata.pdf Nair, D. 2009. Regionalism in the Asia Pacific/ East Asia: A frustrated regionalism. Contemporary Southeast Asia. 31(1): 110-142.

Napoli, C. 2014. China's economic rise; implications for ASEAN Trade Flows. Journal of Southeast Asian Economies 31(3): 345-360.

National Development and Reform Commision. 2015. Vision and actions on jointly building Silk Road economic belt and 21st-century maritime silk road. http://en.ndrc.gov.cn/ newsrelease/201503/t20150330_669367.html

Prime Minister of Japan and His Cabinet, 2015, Provisional Translation Remarks by Prime Minister Shinzo Abe at a Symposium hosted by Sasakawa Peace Foundation USA. http://japan.kantei.go.jp/97_abe/statement/201504/1210942_9918.htm

Sanchita, B.D. 2015. Can the China-led AIIB support the ASEAN connectivity master plan?. ISEAS Perspective No. 30. 24 June. https://www.iseas.edu.sg/images/pdf /iseas_perspective_ 2015_30.pdf

Simon, S. 2008. ASEAN and multilateralism: the long, bumpy road to community, Contemporary Southeast Asia. 30 (2): 264-292.

Sudo, S. 2002. The International Relations of Japan and South East Asia: Forging a new regionalism, London : Routledge

Sudo, S. 2009. Japan's ASEAN policy: reactive or proactive in the face of a rising China in East Asia. Asian Perspective, 33(1). 137-158. http://crawl.prod.proquest.com. s3.amazonaws.com/fpcache/69220c45733de8443c8b062ff60e4e54.pdf?AWSAccessKeyId=AKI AJF7V7KNV2KKY2NUQ\&Expires=1468867886\&Signature=ildoIsL2852JT6CVAi4X12FY9g $\mathrm{s} \% 3 \mathrm{D}$ 
Sudo, S. 2015. Japan's ASEAN Policy: In Search of Proactive Multilateralism, Singapore: Institute of Southeast Asian Studies.

Sutton, M. 2005. Japanese trade policy and 'Economic partnership agreements': a new conventional wisdom. Ritsumeikan Annual Review of International Studies. Vol.4 pp. 113-135. http://www.ritsumei.ac.jp/acd/cg/ir/college/bulletin/e-vol4/sutton.pdf

Sutton, M. 2007. Open regionalism and the Asia Pacific: implications for the rise of an East Asian economic community. Ritsumeikan International Affairs. 5, 133-152. http://www.ritsumei.ac.jp/acd/re/k-rsc/ras/04_publications/ria_en/5-07.pdf

Terada, T. 2015. Japan- ASEAN Partnership in an Era of Multiple Regional Integration Frameworks. In Rizal Sukma \& Soeya, Y. (eds.). Navigating Change: ASEAN-Japan Strategic Partnership in East Asia and in Global Governance. Tokyo: JCIE. http://www.jcie.or.jp/japan/pub/publst/1461/full_report.pdf

Tony, T.T.L. \& Tsai, T.C.2014. Swords into ploughshares? China's soft power strategy in Southeast Asia and its challenges. Revista Brasileira De Politica Internacional. pp.28-48. http://www.scielo.br/pdf/rbpi/v57nspe/0034-7329-rbpi-57-spe-00028.pdf

Urata, S. 2007. Japan's FTA strategy and free trade area of Asia Pacific (FTAAP). PECC/ABAC Joint Study on Free Trade Area of the Asia Pacific (FTAAP). Pacific Economic Cooperation Council.

Urata, S. 2014. Japan's trade policy with Asia. Public Policy Review. 10(1). Policy Research Institute, MOF, Japan. https://www.mof.go.jp/english/pri/publication/pp_review/ppr024/ ppr024a.pdf

Wade, G. 2010. ASEAN divides. New Mandala http://www.newmandala.org/wpcontent/uploads/2010/12/Wade-ASEAN-Divides.pdf

Wang, L. 2011a. China's shifting role and motives in East Asian economic integration: a Chinese perspective on China-ASEAN economic cooperation in the 1990s and 2000s. PhD Thesis, University of Hull.

Wang, L. 2011b. Is China a trade competitior of ASEAN a Chinese perspective on the proposing, cultivation and implications of the CAFTA. Journal of Contemporary Eastern Asia 10 (2). pp. 123. http://eastasia.yu.ac.kr/documents/Wang_10_2.pdf

Wong, L. F. 2007. China-ASEAN and Japan-ASEAN relations during the post-Cold War era. Chinese Journal of International Politics, 1: 373-404.

Zhang, Y., Shen, M. 2013 .FTAs in the Asia-Pacific: a Chinese perspective, Kokusai Mondai (International Affairs) (622). 113. http://www2.jiia.or.jp/en/pdf/publication/2013-06_005kokusaimondai.pdf 